\title{
広範なリンパ節転移を呈した $\mathrm{sm}$ 低分化型虫垂腺癌の 1 例
}

筑波大学附属病院外科, 筑波大学臨床医学系外科*

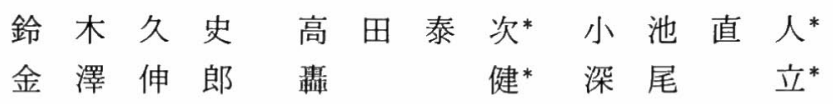

症例は64歳男性で，間質性肺炎にて本院の内科に入院中，右下腹部痛が出現し，急性 虫垂炎の診断のもと, 虫垂切除術が施行された。虫垂は基部で穿孔しており, 蜂巣炎性 虫垂炎の所見であった. 術後の病理組織検査で, 深達度 sm の低分化型虫垂腺癌と診断さ れ, リンパ管浸潤も認められたため, 後日, 右半結腸切除術が施行された。この際, 腸 間膜リンパ節の広範な腫脹を認め, 病理学的にも転移が確認された。

急性虫垂炎様症状に対して虫垂切除術を行った場合, 全例に病理組織診断の必要性が あると考えられた。

索引用語：虫垂腺癌, 低分化型腺癌, リンパ節転移

\section{はじめに}

虫垂癌の中でも，腺癌は比較的稀な疾患で，術前診 断が困難な場合が多い. 急性虫垂炎と診断され，緊急 手術の際に癌と診断されたり, 術後の組織診断によっ て初めて確診が得られたりすることも少なくな ( $^{122}$. 今回われわれは，急性虫垂炎として虫垂切除後 に虫垂腺癌と診断され, 深達度が smでありながら広 範なリンパ節転移を伴った 1 例を経験したので報告す る.

\section{症例}

患者：64歳, 男性.

主訴：右下腹部痛.

家族歴：特記事項なし.

既往歴：間質性肺炎にて本院内科に入院中であっ た。

現病歴：1997年 6 月26日, 右下腹部痛にて発症した。

身体所見：体温37度, 右下腹部に圧痛あり。Blumberg 徵候 $(+)$.

腹部エコー：虫垂が $15 \times 70 \mathrm{~mm}$ に腫大していた（図 1 ).

血液所見 : $\mathrm{RBC} 451 \times 10^{4} / \mathrm{mm}^{3}, \mathrm{Hb} 14.2 \mathrm{~g} / \mathrm{dl}, \mathrm{Ht}$ $42.5 \%$, WBC $17,600 / \mathrm{mm}^{3}$, Plt $329 \times 10^{3} / \mathrm{mm}^{3}$, TP

2001 年 3 月 6 日受付 2001 年 6 月 7 日採用

〈所属施設住所〉

テ305-0005 つくぱ市天久保 2-1-1 8.5g/dl, Alb 3.5g/dl, AST 22IU/l, ALT 15IU/l, LDH 528IU/l, T-Bil 0.6mg/dl, D-Bil 0.2mg/dl, Na $136 \mathrm{mEq} / 1, \mathrm{Cl} 98 \mathrm{mEq} / 1, \mathrm{~K} 4.2 \mathrm{mEq} / 1$, BUN $14.6 \mathrm{mg} /$ $\mathrm{dl}$, Cre $0.6 \mathrm{mg} / \mathrm{dl}$, CRP $6.9 \mathrm{mg} / \mathrm{dl}$, BS $101 \mathrm{mg} / \mathrm{dl}$.

入院後経過：6月26日, 急性虫垂炎と診断し, 緊急 に虫垂切除術を施行した。開腹すると, 腹水を少量認 めた．また，強い浮腫を伴った大網が回盲部を覆って いるのが確認された.この大網を剝離すると, 浮腫を 伴った盲腸と虫垂の一部が現れ, 虫垂根部は第孔を起 こしていた。肉眼的には蜂巣炎性虫垂炎と診断した。

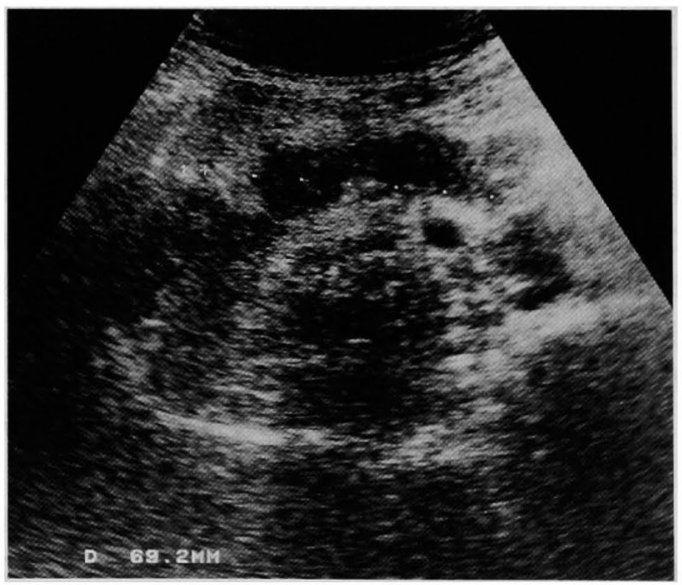

図 1 腹部超音波画像：虫垂が $15 \times 70 \mathrm{~mm}$ に腫大して いた. 

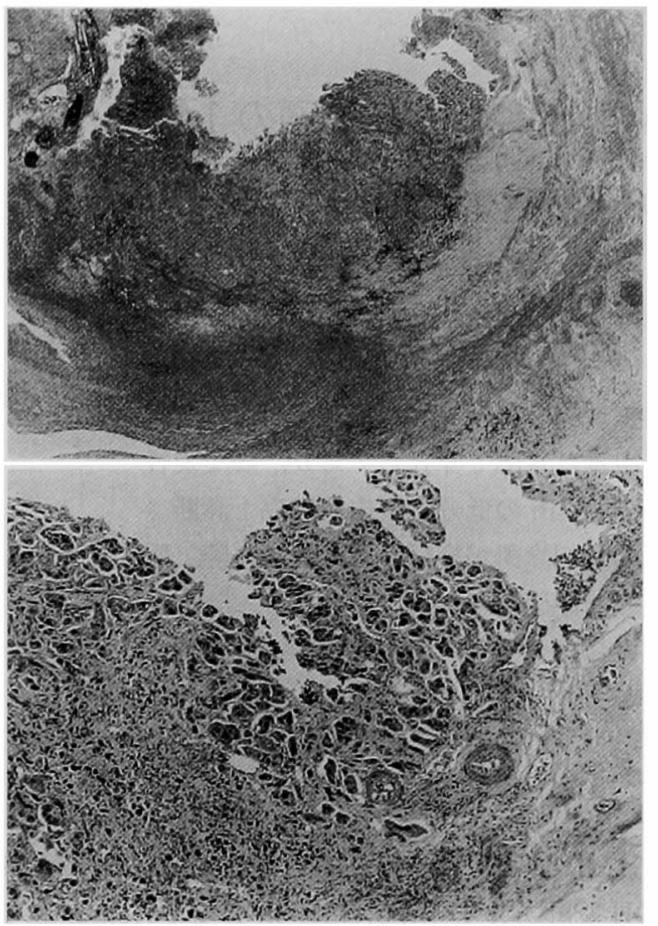

図 2 虫垂の病理組織像: 深達度 $\mathrm{sm}$ の低分化型腺 癌と診断された (H.E.染色, a : × $20, \mathbf{b}: \times 100)$.

しかし, 術後の病理診断にて, 深達度 sm の低分化型腺 癌と診断され,リンパ管侵襲も認められた（図 $2 \mathbf{a}$, b).

虫垂腺癌の診断を得た後に精查を行ったところ, CA19- 9 が $134 \mathrm{U} / \mathrm{ml}$ と上昇し, 注腸造影では癌の遺残 を疑わせる所見はなかったが, 腹部エコーにて10-15 $\mathrm{mm}$ 大に腫大した腸間膜リンパ節が数個認められた。

虫垂切除から 3 週間後, 追加切除目的に再開腹した. 腹腔内を検索すると, 回結腸動脈から上腸間膜動脈に 至るリンパ節, さらに, 空腸起始部の腸間膜リンパ節 の拇指頭大の腫大を認めた。 また, 空腸間膜には, 乳 糜がうっ滞しているような, 乳白色に変化している部 分を認め,さらに空腸の壁内に約 $10 \mathrm{~mm}$ 大の腫瘤を 1 個認めた。

術式は, 右半結腸切除術および空腸部分切除術を施 行した.

術後病理診断にて, 空腸壁内の腫瘤は低分化型虫垂 腺癌の転移であり, SMA 根部の214番リンパ節および 空腸間膜のリンパ節への転移も確認された。腸間膜の 変色は, 下流のリンパ節の腫大によってリンパ流がう
つ滞したためと考えられた.

再切除術後 8 日目, CA19- 9 が122U/ml と依然高値 であったため全身検索を行ったところ, 胸部 CTにて 20-40mm 大の縦隔リンパ節が多数腫大しているのが 認められ，転移と考えられた。

術後35日目より，メソトレキセートと5-FUによる 化学療法を始めたが, 経口摄取不良となり, 間質性肺 炎の悪化による呼吸困難も現れたため，1クールのみ で中止した。その後, 全身状態が次第に悪化し，12月 8 日（術後145病日）死亡した.

\section{考察}

虫垂腺癌は大変稀な疾患で, Collins ${ }^{3)}$ の 71,000 例の 切除虫垂, および剖検例を検討した文献によると, 原 発性虫垂腺癌の発生頻度はわずか57例 $(0.080 \%)$ であ る. 虫垂原発の悪性腫崵のなかではカルチノイドが最 も多く, 腺癌の占める割合は $5.9 \%$ にすぎない.

虫垂腺癌は, 発生様式から，2 つのタイプに分類す ることができる゙).

cystadenocarcinoma（あるいは mucinous adenocarcinoma) と colonic-type adenocarcinoma である，前者は高分化型でムチンを大量に産生し，粘 液腫を作ることで有名である. 後者は, 組織型はほと んどが低分化型で, リンパ行性転移を呈するという特 徵をもって抢り, 今回の症例は, 後者にあたると考え られる。

この colonic-type adenocarcinoma は, 若年から高 齢まで広く分布しているが, 50-60歳台の男性に多い傾 向が見られる ${ }^{51}$. 臨床症状としては, 急性虫垂炎様症状 が多く, 急性虫垂炎の診断のもとに虫垂切除術を行っ て, 病理組織診断にて本疾患と診断されることが多い. 急性虫垂炎は, 緊急手術として扱われる場合が多く, 術前の検查も血液一般検查および腹部 X線写真程度 で, 十分な全身検索が行われることは少ない.しかし, 50-60歳台の男性の急性虫垂炎様症状には, 大腸の悪性 腫畼などの可能性を考慮する必要があり, CT や超音 波検査を行うことが勧められる。虫垂腺癌の中でも, cystadenocarcinoma の場合には CT や超音波によっ て粘液腫を認めることがあるが, colonic-type adenocarcinoma の場合は, 腫瘍がある程度増大しな いと, 術前に診断することは困難であろうと思われる. 治療法は腫瘍の深達度によって決定される. 粘膜層 を超える病変に対して右半結腸切除術が選択される. 虫垂切除のみで治療を終了した場合の術後 5 年生存率 は約 $20 \%$ あるるが, 右半結腸切除術を施行した場合は 
約60\%と報告されている4!。しかし, Robert ら ${ }^{5)}$ は, 外 科的治療を行っても cystadenocarcinoma と比較して colonic-type adenocarcinoma の予後は極めて不良で あると述へている。本症例でも，深達度が smであった ため, 虫垂切除後 3 週間で右半結腸切除術を施行した が，既に小腸間膜リンパ節や小腸壁などへの転移が認 められ，その後も縦隔リンパ節転移が明らかとなり， 術後約 5 カ月で死亡した. Colonic-type adenocarcinoma は早期診断が困難である点も予後不良の一因 であると思われる。

\section{結 語}

今回の症例は，急性虫垂炎椂症状にて発症した虫垂 腺癌 (colonic-type adenocarcinoma) であり, 媣達度 が smでありながら，広範なリンパ節転移を伴った低 分化型腺癌という, 非常に稀な症例であった. 虫垂切 除の術前，術中には本疾患と診断することができず， 切除虫垂から肉眼的に癌を疑うこともできなかった． 今回の経験から, 急性虫垂炎様症状に対して虫垂切除
術を行った場合，全例に病理組織診断の必要性がある と考えられた。

\section{文献}

1) 高田悦雄, 信田重光: 虫垂腺癌. 別冊日本臨牀： 領域別症候群シリース, 6 , 消化管症候群 (下巻), 日本臨床社, 大阪, 1994, p719-722

2）森崎 隆, 佐藤 裕, 岸川英樹他: 原発性虫垂腺 癌の 1 例. 外科 $49: 750-758,1987$

3) Collins DC: 71000 human appendix specimens. A final report, summarizing forty years' study. Am J Proctol $14: 365-381,1963$

4) GT Deans, RAJ Spence : Neoplastic lesions of the appendix. Br J Surgery $82: 299-306,1995$

5) Robert Cortina, Jayne McCormick, Paul Kolm, et al: Management and prognosis of adenocarcinoma of the appendix. Dis Colon Rectum 38 : $848-852,1995$

\title{
POORLY DIFFERENTIATED sm ADENOCARCINOMA OF THE APPENDIX WITH MASSIVE LYMPH NODE METASTASIS-REPORT OF A CASE-
}

\author{
Hisashi SUZUKI, Yasutsugu TAKADA*, Naoto KOIKE*, \\ Noburou KANAZAWA, Takeshi TODOROKI* and Katashi FUKAO* \\ Department of Surgery, University Hospital of Tsukuba \\ -Department of Surgery, Institute of Clinical Medicine, University of Tsukuba
}

A 64-year-old man who was hospitalized with interstitial pneumonia complained of a pain in the right lower abdomen. Under a diagnosis of acute appendicitis, an appendectomy was performed and phlegmonous appendicitis was revealed. But, the pathological diagnosis was poorly differentiated adenocarcinoma, and the depth of invasion of the tumor was submucosa. Lymphatic infiltration was also seen. Three weeks later, a right hemicolectomy was performed, when metastasis of mesenteric lymph nodes were demonstrated macroscopically and microscopically.

We think that pathological examination seems to be necessary for all cases of appendectomy for acute appendicitis like symptoms. 